\title{
READABILITY TEST OF RFID TEMPERATURE SENSOR EMBEDDED IN FRESH CONCRETE
}

\author{
Julian H. Kang ${ }^{1}$, Jasdeep Gandhi ${ }^{2}$ \\ ${ }^{1}$ Department of Construction Science, Texas A\&M University, 3137 TAMU, \\ College Station, TX 77843-3137, e-mail: ${ }^{1}$ juliankang@tamu.edu (corresponding author) \\ ${ }^{2}$ Adolfson Peterson Construction, U.S.A \\ Received 10 Mar. 2010; accepted 15 May 2010
}

\begin{abstract}
Concrete maturity technology is used to predict the strength of concrete being cured and make an informed decision for stripping the formworks. However, the current concrete maturity method uses temperature sensors that require an extensive wiring, which is not often acceptable on construction site due to harsh working environment. Radio Frequency Identification (RFID) technology provides a solution for the wiring issue because of its ability of sending data wirelessly. An RFID tag integrated with a temperature sensor and placed within fresh concrete may be able to read temperatures of concrete and transmit them to an RFID reader wirelessly in real-time. It may then enable construction professionals to use concrete maturity technology to make an informed decision for stripping the formworks without having to worry about wiring issues on construction site. However, the previous research indicated that the RFID signal gets dispersed in liquid medium. One may speculate then how well RFID signals can travel through fresh concrete with high water content. Would water content of fresh concrete affect the readability of RFID tags? Would the tag's burying depth within fresh concrete affect its readability? This paper presents the results of our investigation on the readability of RFID tags placed in fresh concrete in the early stage of the curing process.
\end{abstract}

Keywords: RFID; Concrete Maturity.

\section{Introduction}

Many forensic case studies of concrete construction report that failures of reinforced concrete structures take place often during construction (Ghosh 2008). American Concrete Institute reports that these failures are mainly caused by formwork failures that usually occur when fresh concrete is being placed (Hurd 2005). The formwork is not usually stable enough to handle the weight of wet concrete. Any unexpected event can cause the failure of one member, which makes other members overloaded, and eventually results in the collapse of the entire formwork. The premature removal of formwork and shores, motivated by a desire to speed up the construction process, is also one of the main causes of sudden collapse of concrete buildings under construction. Fourteen workers were killed and 34 were injured when the multi-story building in Fairfax County, Virginia collapsed in 1973 during construction (Leyendecker and Fattal 1977). Fiftyone workers were killed when the cooling tower in Willow Island, West Virginia collapsed in 1978 during construction (Lew 1982). Both incidents were caused by early removal of forms from the cast-in-place concrete structure. The construction failure of the condominium building in Cocoa Beach in Florida (Lew et al. 1982a, $1982 \mathrm{~b}$ ) is also one of the well-known collapses during construction. Premature removal of formwork coupled with insufficient concrete strength resulted in punching shear failure at the slab-column connection and triggered the vertical collapse in a progressive manner to the ground (Ghosh 2008).

Estimating the strength development in the cast-inplace concrete structures at the early stage of the curing process has been of a major interest among construction professionals who want to speed up the concrete placement process but still secure the stability of the structure.

Using test cylinders is one of the most popular methods to figure out the strength development of fresh concrete placed in the formwork. Test cylinders produced when concrete is being placed on the jobsite are tested to measure their strength periodically. When the strength of a test cylinder exceeds a certain capacity, a project manager gains confidence that the concrete structure on the jobsite is strong enough to stand by itself, so it is safe to remove the formwork and shores.

However, the strength development pattern of the test cylinders can be different than that of the in-place concrete structure partially due to different curing conditions and environment. This may sometimes result in inaccurate reflection of the actual concrete strength development. For example, the Cocoa Beach condominium construction project used the laboratory-cured cylinders instead of the field-cured cylinders and failed to determine the actual strength of the concrete slabs, which contributed to the collapse of the building during construction (Ghosh 2008). 
The best way to figure out the strength development of the cast-in-place concrete structure at its early stage of the curing process would be measuring its strength directly. Many non-destructive methods were suggested to measure the strength of the field concrete at the early stage of its curing process. The concrete maturity method is one of them.

\section{Concrete Maturity}

The concrete maturity method comes from discovering the relationship between the thermal history of concrete and its strength development at the early stage of the hydration process (McDaniel 1915; Wiley 1929; Timms and Withey 1934). Temperature within the cast-in-place concrete increases as time goes by because of the chemical reaction between cement and water. Understanding the co-relationship between this temperature change and concrete strength development gives us a chance to estimate concrete strength at a certain time during the concrete curing process (McIntosh 1949; Nurse 1949; Saul 1951; Price 1951; Bergstrom 1953). The timetemperature relationship is called maturity, which is defined as a function of time and temperature. Many maturity functions, including the Nurse-Saul maturity function (Saul 1951) and the Arrhenius maturity function (Freiesleben-Hansen 1977), have been proposed and verified (Naik 1985; Carino and Lew 2001) since the early 1950s. The Nurse-Saul maturity function defines the maturity index of cast-in-place concrete using temperature changes within the concrete and the elapsed time. The Arrhenius maturity function is suggested to convert the actual age of the concrete to its equivalent age in terms of strength gained at the reference temperature. If these functions can be used to determine the strength of concrete in real-time, all we would have to do is to measure the temperature within concrete.

Goodrum and Dai (2004) demonstrated, from the pilot project conducted in Puerto Rico, that the in-situ concrete strength can be more accurately and consistently determined by the concrete maturity method than with other conventional methods. However, he also reported that it was not easy to keep wires connected between data loggers and the computer system. Goodrum's report suggests that the concrete maturity method can be better applied on construction sites if the wiring issue is resolved. One of the off-the-shelf technologies that may enable us to eliminate the use of wire is Radio Frequency Identification (RFID) technology.

\section{Radio Frequency Identification (RFID)}

Radio Frequency Identification (RFID) is a general term used to define any system that uses radio waves to transmit a unique identification number to an antenna. The RFID system consists of basically two main components: tag and reader. The memory in the tag contains a unique serial number and this serial number gets transmitted to the reader wirelessly.

RFID technology gained attention mainly because of limitations of the barcode systems. The ubiquitous auto-id technology called barcodes was considered as a revolution when it was first applied to a rail car tracking system in late 1960s. The optical CARTRAK system, developed by IBM, was based on a reflective multicolored barcode attached on the side of each railroad car. This system was designed to read the barcode on each car when it passed the optical reader in the station, and put it in a database. However, it was often difficult to scan the barcode accurately because of the problems that continues today: need of line of sight, dirt and scratches in the barcode, low durability, and low storage capacity (Shepard 2005). Professionals were attracted to RFID technology because it appeared to have some advantages that may solve the problems with barcodes.

The concept of RFID was first introduced in World War II. During the war, radar technology was developed to warn approaching airplanes of while they were still miles away. The first generation of radar technology, however, was not able to identify whether these airplanes belonged to the enemy or not. It was discovered one day that the radio signal pattern detected at the radar station was distinctively different when the airplanes were rolling. The German pilots used this simple trick to inform the radar crew on the ground of their coming back (Rieback 2006). Later the United Kingdom developed a device, called Identification Friend or Foe (IFF), to distinguish their airplanes from the enemy's airplanes. In this system, a transponder placed in airplanes sent a signal identifying itself upon receiving the signal from the radar (Bowden 1985). Shepard (2005) noted that RFID works on the same basic concept. RFID readers send an energy beam to wake up tags, and detect a signal emitted by the tags.

After research advances in the 1950s and 1960s, RFID technology started to be utilized for commercial purposes. Companies such as Checkpoint and Sensormatic developed electronic article surveillance systems, which were designed to detect a 1-bit tag when it passed a checkpoint. If a shoplifter carried a piece of merchandise through the checkpoint with the tag attached and activated, an alarm would sound. RFID technology continued to evolve in 1970s, and its application was expanded to vehicle tracking. Mario Cardullo came up with the first RFID-like tag that consisted of a transmitter, a receiver, a small amount of internal memory, and a dedicated power source. He continued to refine this concept and eventually developed an automated tool collection system, which was tested by the Port Authority of New York and New Jersey (Landt 2001; Shepard 2005). In 1990s, RFID was introduced to the department of transportation through the electronic tolling system. The first highway electronic tolling system, which allowed vehicles to pass the checkpoint at highway speed, was installed in Oklahoma in 1991 (Landt 2001).

\section{Concrete Maturity and RFID}

The concrete maturity method uses a temperature sensor and temperature recording device. Before fresh concrete is placed, the electronic temperature sensors are placed in the formwork and connected to the recording devices 
with the use of wires. Installing wires on construction sites to connect all temperature devices with the recording devices may not be practical because of the harsh nature of construction sites. The network of wires may easily loose connections. Therefore, maintaining the wire network on construction sites while concrete is being cured is a challenge.

To overcome disadvantages of the wire network, various wireless sensors are being developed. One of the recent developments is the use of the sacrificial RFID tags integrated with the temperature sensor. The sacrificial RFID sensors are embedded in concrete to detect the temperature changes over time while concrete is being cured, and send their readings to a reading device (Goodrum and Dai 2004). With the use of sacrificial RFID sensors, it is expected that the maturity and strength of castin-place concrete can be easily monitored in real time for 24 hours without having to deal with the wire network problems. Michigan Department of Transportation demonstrated the application the RFID temperature sensors to a road construction (Greenwood 2003; Hansen and Surlaker 2006).

\section{Motivation}

Previous research found that the RFID readability decreases or stops if the tag is submerged in water (Schneider 2003; Fletcher et al. 2005). The pilot study implemented by Proctor \& Gamble reported that the RFID tags attached to liquid products such as liquid detergents were not easily detected while powdered detergents were easier to track (Brewin 2004). These findings suggest that RFID tags located in fresh concrete in the early stage of the curing process may not be well detected by the recoding device because of the high water content in concrete. However, understanding that the hydration process of concrete consumes water, it would be also reasonable to expect that the readability of the RF signals should increase as time elapses because the water content in concrete decreases as the hydration process takes place. One may then ask then when exactly we would be able to detect the RF signals. Would it be possible to detect the RF signals on time and make an informed decision to strip the form? This question motivated our research team to figure out how the RFID signals emitted within fresh concrete at various depths gets detected at the early stage of the curing process.

\section{Experiment}

The research team assumed that three variables may affect the readability of the RF signals: 1 ) the burying depth of RFID tags, 2) the distance of the reader from the tag, and 3) time elapsed since the concrete is placed. The readability of the RF signals against these variables could be determined by monitoring the strength of the RF signals emitted from the RFID tags placed in a concrete block during its hydration process. The research team fabricated 4 formworks, and put 3 RFID tags at 3 different locations within each formwork. After placing fresh concrete into these formworks, the strength of the RF signals was measured at various distances from the concrete block.

\subsection{RFID tags selected for the test}

RFID tags come in different sizes, shapes, and ranges. Tags also can be divided into two types: 1) passive tags or 2) active tags. Passive tags do not contain batteries. They generate energy using electromagnetic power emitted by the reader's antenna. The reader therefore should be close to the tag to get it charged. Active tags have their own battery. They are used for long-range applications. Some active RFID tags are combined with other sensors. For this test, we decided to use an active RFID tag integrated with a temperature sensor. It was designed to read temperature periodically and emit its reading.

The RFID transponder and reader operate in three ranges of frequencies: 1) Low Frequency, 2) High Frequency, and 3) Ultra High-Frequency (UHF). Lowfrequency devices operate between 125 to $134 \mathrm{KHz}$ and have a reading range of about 12 inches. High-frequency devices use the range of 3 to $30 \mathrm{MHz}$, and generally operate at $13.56 \mathrm{MHz}$. UHF devices operate in a range of 400 to $950 \mathrm{MHz}$ and have the highest reading range. Every frequency range has its own merit and demerits. Lower frequency range devices use minimum power and are inexpensive. Its performance is affected by noise but is unaffected by metals and orientation. Higher frequency systems have properties opposite to the lower-frequency. These use more power, have longer reading range, and are more expensive than lower frequency systems (Shepard 2005). The RFID tags selected for this test uses an Ultra High-Frequency wave over $800 \mathrm{MHz}$.

\subsection{Reader}

The reader used for the test was a fully compliant PCMCIA (Personal Computer Memory Card International Association) Type II card. It can transform any compatible laptop, handheld, or other computing device into a powerful Intelligent Long Range (ILR) active reader with a range of $300 \mathrm{ft}$. For our test, a laptop computer with the PCMCIA Type II card inserted served as a RFID reader.

\subsection{Size of concrete blocks}

Considering the various types and sizes of concrete members, it would not be possible to produce a generalized outcome unless a significant amount of cases were tested. Before getting into a full investigation, we decided to test a limited amount of cases in terms of tag location. The result of this test would allow us to see the trend and come up with a test for full-scale investigation. After looking up various sizes of concrete components used for commercial buildings in Texas, we determined to use a $2 \mathrm{ft} \times 2 \mathrm{ft} \times 2 \mathrm{ft}$ concrete block. However, the RFID tag selected for our test was a 5-inch long slim block $(5.15 \mathrm{in} \times 1.1 \mathrm{in} \times 0.8 \mathrm{in})$. Therefore, both ends of the tag in longitudinal way would be located 2.5 inch closer to the surface of the concrete block than other surface of the tag, if the tag is place in the middle of a cubic. The RF signals 
emitted through the longitudinal end of the tag would be able to hit the surface of the concrete block faster, which may bias the test result. In order to handle this issue, we decided to increase the size of the concrete Block to $3 \mathrm{ft} \times 2 \mathrm{ft} \times 2 \mathrm{ft}$. Four formworks of this size were prepared for the test.

\subsection{Tag location}

According to the vendor's information, the RFID tag selected for our test is capable of sending signals as far as $300 \mathrm{ft}$ over the air. We placed three tags in the concrete block in such a way that they were at the same distance from top and front of the concrete block. After considering the tag's thickness of 1.1 inch, we decided to place the tag in every 4 inches, which leaves a gap of about 3 inches between tags. The tags were placed in such a way that their longer side was parallel to the longer edge of the box. This was to ensure that the signals emitted from the tag would travel approximately the same distance. The tags were held by nylon thread and wooden dowels at 4 inches, 8 inches, and 12 inches from the surface as shown in the Fig. 1.

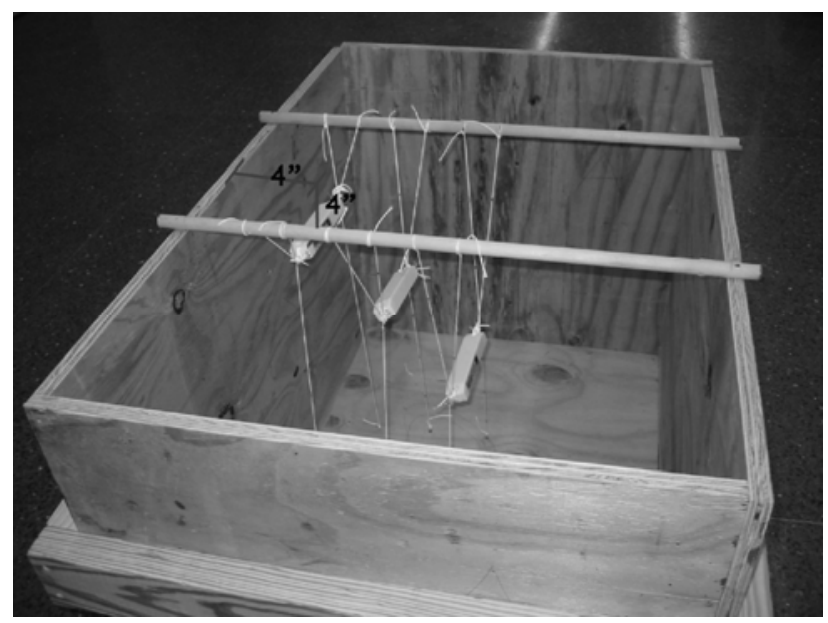

Fig. 1. Tag locations

\subsection{Concrete}

We used ready mix concrete for all 4 blocks to make sure that we didn't get different results due to different concrete property. The concrete's target strength was 3,000 psi. The slump of concrete marked 5 inches. The water cement ratio of the concrete was 0.53 by volume.

\section{Implementation of Experiment}

The experiment was carried out at an open ground in Texas. The concrete was poured slowly into the formworks in order to avoid any damage to the strings holding the tag. The test started in October, and continued for 13 days. Highest temperature during the test period was $90^{\circ} \mathrm{F}$ and lowest temperature was $42^{\circ} \mathrm{F}$. Humidity changed somewhere between $50 \%$ and $80 \%$.

\section{Test Results}

The tags embedded in either 4 inches or 8 inches from the surface started giving readings 3 to 4 hours after concrete was placed. The tags embedded in 4 inches were able to transmit signal to a distance of $60 \mathrm{ft}$. The travel distance of the tags embedded in 8 inches was limited to a range of $30 \mathrm{ft}$. The signals from the tags embedded at the depth of 12 inches were weakest of all. After 7 days the range of the tags increased considerably. The tags at the depth of 8 inches were able to transmit signal to a distance of $45 \mathrm{ft}$. The tags at the depth of 12 inches were able to transfer data to a range of $15 \mathrm{ft}$.

A distance versus time graph was prepared for every tag, which marks the time at which the tag started giving the signal at a particular distance. Fig. 2 shows variation of the range of the tags at depth of 4 inches from the surface with time. The tag in Block 1 started giving the signal 4.5 hours after pouring the concrete. The reading range of the tag in Block 1 suddenly increased 23 hours after pouring the concrete. The tag in Block 2 started transmitting just 1 hour after concrete was placed. The range of the tag increased with time. After 21 hours elapsed after concrete was poured, the tag started transmitting signal to the range of $60 \mathrm{ft}$. The tag in block 3 started sending signal 3 hours after the concrete placement. There was a sudden increase in 20 hours after the concrete was placed. The tag installed in Block 4 started responding to the reader after 3 hours. All the tags showed similar trend with time. The tags were not responding for the first three hours after pouring the concrete when the water ratio was high in concrete. This illustrates our speculation that RFID might not be able to transmit the signal in fresh concrete. There was an increase in reading range as the concrete matured and the water content of the concrete deceased.

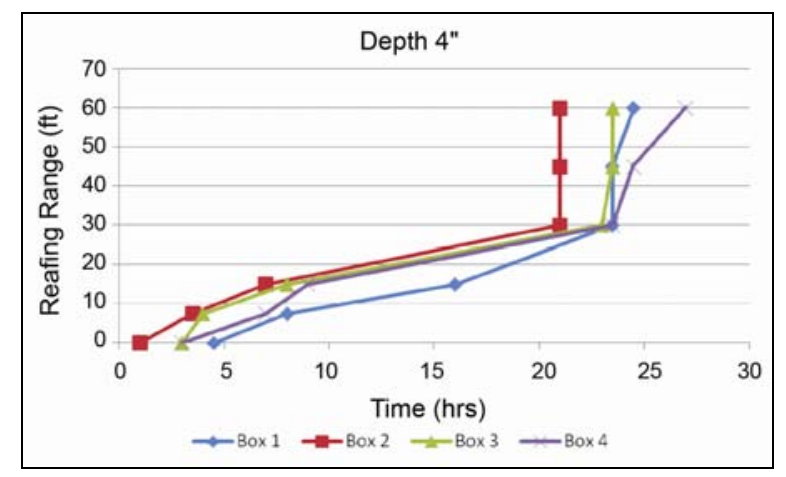

Fig. 2. Reading range of RFID tags installed 4 inches from the surface of the concrete block

Fig. 3 illustrates an increase in the reading range of tags embedded at 8 inches with time. The reading range was stabilized after a gradual increase until 26 hours after the time of pouring. The tags showed the increase in the reading range after 7 days of pouring.

Fig. 4 shows the reading range variation of tags buried at the depth of 12 inches. These tags were the last to respond and showed a lower reading range as compared with the tags at 4 inches or 8 inches in depth. The reading range of the tags was $15 \mathrm{ft}$ when 7 days elapsed after the time of pouring. 


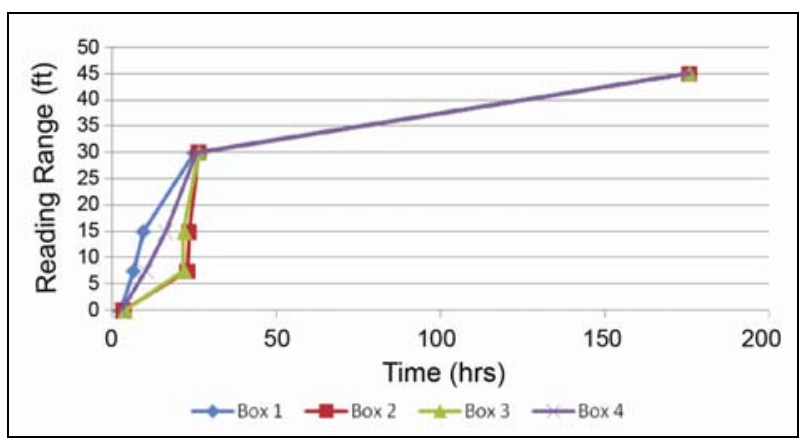

Fig. 3. Reading range of RFID tags installed 8 inches from the surface of the concrete block

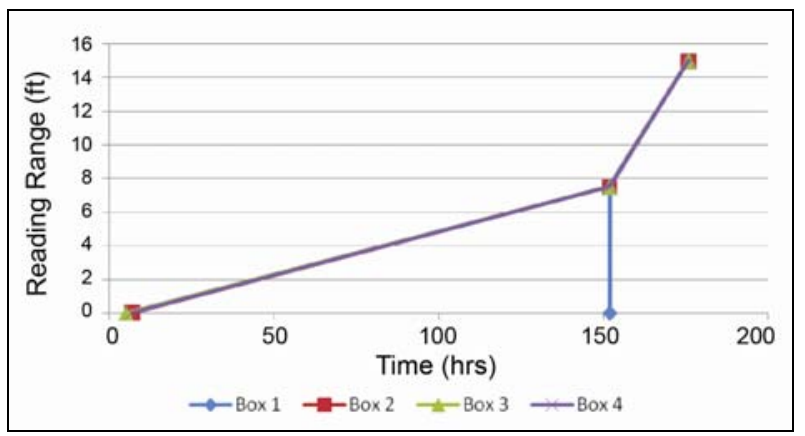

Fig. 4. Reading range of RFID tags installed 12 inches from the surface of the concrete block

\section{Analysis}

The tags embedded at 4 inches in the concrete block were first to respond after the pouring of the concrete and were the earliest to reach an increased reading range. The tags at 12 inches in the concrete block were the last to respond and were last to get to the subsequent reading range. This observation suggests that the readability of the RFID tags is reversely proportional to the burying depth of the tags within the concrete block.

The tags placed in fresh concrete were not able to transmit the signal for the first 3 hours, but as the concrete matured and the water content in concrete decreased, the tags started transmitting signal. The RF signals emitted from 4 inches or 8 inches in the concrete block were detected at a distance of 30 feet in 3 days. However, the RF signals emitted from 12 inches in the concrete block were not detected at a distance of 30 feet even after 7 days. This observation suggests that tags embedded in less than 8 inches from the surface of the concrete block can be effectively utilized to determine the concrete maturity.

\section{Conclusion}

In theory, concrete maturity technology can be used to make an informed decision to strip the formworks. However, the current concrete maturity method uses temperature sensors that require an extensive wiring, which is not often acceptable on the construction site. Radio Frequency Identification (RFID) tags integrated with a temperature sensor could be an alternative solution. However, the readability of the RFID tags in fresh concrete is expected to decrease due to high water content. Our research team was wondering if it was possible to detect the RF signals on time and make an informed decision to strip the form. More specifically we tried to figure out how the RFID signals emitted at various depths within fresh concrete get detected at the early stage of the curing process. In order to figure it out, the research team fabricated 4 formworks, and put 3 RFID tags at 3 different locations within each formwork. After poring fresh concrete into these formworks, the strength of the RF signals was measured at various distances from the concrete block.

Our test discovered that:

- The reading range of the RFID tags was inversely proportional to the burying depth of the tag within concrete.

- The signal of the RFID tags did not travel for the first 3 hours when they were imbedded in fresh concrete.

- The RF signals emitted from 4 inches or 8 inches in the concrete block were detected at a distance of 30 feet in 3 days.

- The RF signals emitted from 12 inches in the concrete block were not detected at a distance of 30 feet even after 7 days.

- The reading range of the RFID tags increased with time.

Although the results from this experiment cannot be generalized for the whole industry because a limited number of cases were tested using RFID tags provided by just one vendor, the preliminary findings suggest that the Ultra High Frequency (UHF) active RFID tags integrated with the temperature sensor can be used for the concrete maturity method if they are embedded in less then 8 inches from the surface of concrete block. However, the tag embedded at a greater depth did not transmit the signal to the reader effectively even after a certain hydration process took place. This variation may not be just because of the water content in concrete. The reading range may also be affected by something relative to the concrete composition. Further investigation therefore should be implemented to figure out the reason for this incident. The variations in the reading range can be enticing for the researchers in the construction industry. Similar experiments should be carried out with tags from different vendors and at different locations.

\section{References}

Bergstrom, S. C. 1953. Curing Temperature, Age and Strength of Concrete, Magazine of Concrete Research 4(14): 61-66.

Bowden, L. 1985. The story of IFF (Identification Friend or Foe), Physical Science, Measurement and Instrumentation, Management and Education, Reviews, IEE Proceedings A 132(6): 435-437.

Brewin, B. 2004. Consumer packaged goods firms: No quick ROI from RFID. Computerworld.

Carino, N. J.; Lew, H. S. 2001. The Maturity Method: From Theory to Application, in Proceedings of the 2001 Structures Congress \& Exposition, American Society of Civil Engineers (ASCE), 1-19.

Fletcher, R.; Marti, U. P.; Redemske, R. 2005. Study of UHF RFID Signal Propagation through Complex Media, in IEEE Antennas and Propagations Society International Symposium 1B: 747-750. 
Freiesleben-Hansen, P. 1977. Maleinstrument til kontrol af betons haerdning, Nordisk Betong, 21-25.

Ghosh, S. K. 2008. Construction Loading in High-Rise Buildings, Concrete Construction Engineering Handbook. Editor: Edward G. Nawy, Chapter 8, CRC Press. Publisher: CRC Press.

Goodrum, P. M.; Dai, J. 2004. The Use of Concrete Maturity Method in the Construction of Industrial Facilities: A Case Study. FIATECH.

Greenwood, T. 2003. Meter cuts the costs of testing new concrete, The Detroit News July 17, 2003.

Hansen, W.; Surlaker, S. 2006. Embedded Wireless Temperature Monitoring Systems For Concrete Quality Control. University of Michigan, Ann Arbor.

Hurd, M. K. 2005. Formwork for Concrete, ACI Committee 347, Special Publication Number 4, Seventh Edition, American Concrete Institute (ACI), Farmington Hills, Michigan.

Landt, J. 2001. Shrouds of Time: The History of RFID, AIM, Inc.

Landt, J. 2005. The history of RFID, IEEE Potentials 24(4): 811. doi:10.1109/MP.2005.1549751

Lew, H. S. 1982. Investigation of construction failure of reinforced concrete cooling tower at Willow Island, $W V$, NBS Building Science Series No. 148. National Bureau of Standards (NBS), Washington, D.C.

Lew, H. S.; Carino, N. J.; Fattal, S. G.; Batts, M. E. 1982a. Investigation of the Construction Failure of Harbour Cay Condominium in Cocoa Beach, FL. NBS Building Science Series No. 145. National Bureau of Standards, Washington, D.C.

Lew, H. S.; Carino, M. J.; Fattal, S. G. 1982b. Cause of the condominium collapse in Cocoa Beach, FL. Concrete Int. 4(8): 64-73.

Leyendecker, E. V.; Fattal, S. G. 1977. Investigation of the Skyline Plaza Collapse in Fairfax County, Virginia, Building Science Series No. 94, 88 p. National Bureau of Standards, Washington, D.C.
McDaniel, A. B. 1915. Influences of Temperature on the Strength, University of Illinois Engineers Experiment Station Bulletin, No. 81.

McIntosh, J. D. 1949. Electrical Curing of Concrete, Magazine of Concrete Research 1(1): 21-28.

Naik, T. R. 1985. Maturity Functions for Concrete Cured During Winter Conditions, in Symposium on Temperature Effects on Concrete, ASTM Special Technical Publication 858, 107-117.

Nurse, R. W. 1949. Steam Curing of Concrete, Magazine of Concrete Research 1(2): 79-88.

Price, W. H. 1951. Factors influencing Concrete Strength, in Proceedings, American Concrete Institute 47: 417-432.

Ramussen, R. O.; Cable, J. K.; Voigt, G. F.; Turner, D. J. 2004. Strength Prediction by Using Maturity for Portland Cement Concrete Pavement Construction at Airfields, Journal of the Transportation Reseearch Board 1893: 18-25. doi:10.3141/1893-03

Rieback, M. R.; Crispo, B.; Tanenbaum, A. S. 2006. The evolution of RFID security, Pervasive Computing, IEEE 5(1): 62-69. doi:10.1109/MPRV.2006.17

Saul, A. G. A. 1951. Principles Underlying the Steam Curing of Concrete at Atmospheric Pressure, Magazine of Concrete Research 2(6): 127-140.

Schneider, M. 2003. Radio Frequency Identification (RFID) Technology and its Applications in the Commercial Construction Industry. Masters Thesis, University of Kentucky.

Shepard, S. 2005. RFID: Radio Frequency Identification. McGraw-Hill Professional.

Timms, A. G.; Withey, N. H. 1934. Temperature Effects on the Compressive Strength of Concrete, in Proceedings of the American Concrete Institute 30: 159-180.

Wiley, C. C. 1929. Effect of Temperature on the Strength of Concrete, Engineering News Record 102(5): 179-181.

\section{RND TEMPERATŪROS JUTIKLIO, DEDAMO İ ŠVIEŽIĄ BETONĄ, SKAITOMOSIOS GEBOS BANDYMAS}

\section{J. H. Kang, J. Gandhi}

Santrauka

Betono stiprèjimo technologija taikoma apdorojamo betono stiprumui prognozuoti priimant sprendimą, kada galima nuimti klojinius. Vadovaujantis betono stiprèjimo kontrolès metodu, naudojami temperatūros jutikliai, prijungiami laidais, kuriuos ne visada patogu naudoti sunkiomis statybos aikštelès sąlygomis. Laidų galima atsisakyti taikant radijo dažnio nustatymo (RDN) technologija, nes ji leidžia siųsti duomenis be laidų. RND siųstuvas, pritvirtintas prie temperatūros jutiklio ir įdètas i ́ šviežią betona, gali matuoti betono temperatūrą ir perduoti jos reikšmes i RND imtuvą be jokių laidų. Remiantis tokia informacija galima spręsti, kada nuimti klojinius nesukeliant rūpesčiu su jutikliu laidais. Tačiau ankstesni tyrimai parodè, kad skystoje aplinkoje RDN signalas išsklaidomas. Galima tik spèti, kaip šis signalas sklis šviežio betono aplinkoje. Ar tokiame betone esantis vanduo leis skaityti RND siųstuvų informaciją? Ar siųstuvo gylis šviežiame betone komplikuos jo informacijos skaitymo galimybę? Šiame straipsnyje aprašomi RND siųstuvų informacijos tyrimo rezultatai, gauti įdèjus siųstuvus ankstyvuoju šviežio betono stiprèjimo laikotarpiu.

Reikšminiai žodžiai: radijo dažnio nustatymas, betono stiprẻjimas.

Julian H. KANG is a Harold L. Adams endowed associate professor and graduate program coordinator of Construction Science at Texas A\&M University. His primary research interests include Virtual Design and Construction, Stochastic Construction Simulation, and Radio Frequency Identification (RFID). He is interested in investigating how these emerging technologies contribute to the productivity improvement in construction. He is a member of ASCE. He is also a member of ACI Committee 131 Building Information Modeling (BIM) of Concrete Structures and chairs its sub-committee for training. He co-chairs the BIM Texas 2010 Conference. Jasdeep S. Gandhi received his Master's degree in Construction Management from Texas A\&M University. He has done his bachelors from Maulana Azad National Institute of Technology in India. He is a Certified Associate in Project Management and member of Project Management Institute (PMI). He is also a LEED Accredited Professional and member of USGBC. His areas of research include Radio Frequency Identification (RFID) in construction, Building Information Modeling (BIM), and Green Buildings.

Jasdeep S. GANDHI received his Master's degree in Construction Management from Texas A\&M University. He has done his bachelors from Maulana Azad National Institute of Technology in India. He is a Certified Associate in Project Management and member of Project Management Institute(PMI). He is also a LEED Accredited Professional and member of USGBC. His areas of research include Radio Frequency Identification (RFID) in construction, Building Information Modeling (BIM), and Green Buildings. 